\title{
Outcome after severe non-accidental head injury
}

\author{
J Haviland, R I Ross Russell
}

\begin{abstract}
Over the past three years 15 children have been admitted to the paediatric intensive care unit (PICU) at Addenbrooke's hospital suspected of having non-accidental injuries; presentation was diverse and often mild and out of proportion to the degree of morbidity seen at discharge and follow up. When compared with a group of similar aged children admitted to the PICU with severe head injury caused by accidental impact trauma, the differences in morbidity were profound. It is suggested that these differences are explained in part by the predominant repetitive rotational forces experienced during severe shaking compared with the translocational forces that the head experiences during impact injuries. This anecdotal evidence supports the theory that shaking alone may cause severe intracranial injury. Thus campaigns should continue to increase public and doctors' awareness that shaking may be dangerous.
\end{abstract}

(Arch Dis Child 1997;77:504-507)

Keywords: shaking injury; non-accidental injury

Children subjected to non-accidental injury (NAI) rarely require paediatric intensive care, although a small proportion do suffer injuries severe enough to make this necessary.

It has been reported that the morbidity and mortality of these patients is very high, ${ }^{1-4}$ but there are few data on the longer term physical and social outcomes of such abuse. ${ }^{5}$ We have reviewed our own experience of infants and children requiring paediatric intensive care over the past three years to look at the presentation, physical signs, and severity of head injury. In particular, we have reviewed the physical and social outcomes. Injuries in these children are believed to be a combination of impact trauma (acceleration/deceleration injury) and shaking (rotational/shearing injury), although the relative contribution of these factors is debated. ${ }^{16-8}$ In order to evaluate this further, we compared our patients with an age matched group of children who had suffered

Paediatric

Department, Box 181, Addenbrooke's Hospital, Hills Road, Cambridge CB2 2QQ

J Haviland

R I Ross Russell

Correspondence and reprint requests to:

Dr Ross Russell.

Accepted 22 August 1997 as victims of NAI if all these features present: severe injuries inconsistent with the medical history; clinical, radiological, and/or
Admission records to our regional paediatric intensive care unit (PICU) over the past three years were scanned and 15 children were identified with NAI. Children were classified ophthalmic evidence suggesting NAI; and sufficient clinical confidence in the diagnosis to involve the police and social services. Data were retrieved from the notes of each child, including details on presentation, physical examination, investigations, and physical outcome at discharge. Computed tomograms and skeletal surveys were reported by a consultant neuroradiologist or paediatric radiologist and ophthalmic examination performed by a senior registrar or consultant ophthalmologist. An age matched group of children was also studied comprising all children under 2 years old who were admitted with isolated head trauma. Details of the extent of cranial injury and physical outcome at discharge were collected.

We investigated the long term social outcome of the NAI group. The key careworker involved in each case was contacted and asked to give information as to the child's present neurological state and level of function. This was later categorised, with help from outpatient records, into normal, mildly, moderately, or severely handicapped. The current care arrangements, present carers, and the outcome of police investigations and prosecutions, if any, were noted. Follow up varied from three months to three years.

\section{Results}

Fifteen children were identified with a median age of 3 months (range 1-30 months) (table 1). All but one patient were under 9 months. Table 1 gives details of presentation, table 2 details of physical examination, and table 3 findings on radiological examination. All 15 children had significant cerebral injury consistent with shaking. Presentation was diverse, however, often mild and non-specific. Apnoea was a common feature $(47 \%)$. Gastrointestinal complaints included poor feeding, diarrhoea, vomiting, and melaena. The most common feature was unexplained fits (47\%). Lethargy, drowsiness, and irritability were no more common than the gastrointestinal complaints. Two patients presented after their parents were unable to rouse them. Thirteen cases were transferred from other hospitals and only six of these were initially suspected as suffering from NAI.

Despite the non-specific presentation, all 15 children showed clinical evidence of severe injury. Twelve of the 15 patients $(80 \%)$ developed seizures during admission, irritability was noted in six $(40 \%)$, and lethargy or a decreased level of consciousness was also seen in six $(40 \%)$. Signs of increased intracranial pressure were common. A full fontanelle was noted in 10 children $(67 \%)$, with radiological cerebral oedema noted in half of these; a head 
Table 1 Symptoms of patients at presentation $(Y=$ present $N=$ not present $)$

\begin{tabular}{|c|c|c|c|c|c|c|c|c|c|c|}
\hline $\begin{array}{l}\text { Child } \\
\text { No }\end{array}$ & $\begin{array}{l}\text { Age } \\
\text { (months) }\end{array}$ & Fits & Unresponsive & Lethargic & Drowsy & Irritable & Apnoea & $\begin{array}{l}\text { Poor } \\
\text { feeding }\end{array}$ & Diarrhoea & Vomiting \\
\hline 1 & 3 & $\mathrm{Y}$ & $\mathrm{N}$ & $\mathrm{N}$ & $\mathrm{Y}$ & $\mathrm{N}$ & $\mathrm{N}$ & $\mathrm{N}$ & $\mathrm{Y}$ & $\mathrm{N}$ \\
\hline 2 & 1.3 & $\mathrm{~N}$ & $\mathrm{~N}$ & $\mathrm{~N}$ & $\mathrm{~N}$ & $\mathrm{~N}$ & $\mathrm{~N}$ & $\mathrm{Y}$ & $\mathrm{Y}$ & $\mathrm{N}$ \\
\hline 3 & 8 & $\mathrm{~N}$ & $\mathrm{Y}$ & $\mathrm{N}$ & $\mathrm{N}$ & $\mathrm{N}$ & $\mathrm{N}$ & $\mathrm{N}$ & $\mathrm{N}$ & $\mathrm{N}$ \\
\hline 4 & 4 & $\mathrm{Y}$ & $\mathrm{N}$ & $\mathrm{N}$ & $\mathrm{N}$ & $\mathrm{N}$ & $\mathrm{N}$ & $\mathrm{Y}$ & $\mathrm{Y}$ & $\mathrm{N}$ \\
\hline 5 & 30 & $\mathrm{Y}$ & $\mathrm{N}$ & $\mathrm{N}$ & $\mathrm{N}$ & $\mathrm{N}$ & $\mathrm{N}$ & $\mathrm{N}$ & $\mathrm{N}$ & $\mathrm{Y}$ \\
\hline 6 & 4 & $\mathrm{~N}$ & $\mathrm{~N}$ & $\mathrm{~N}$ & $\mathrm{~N}$ & $\mathrm{~N}$ & $\mathrm{Y}$ & $\mathrm{N}$ & $\mathrm{N}$ & $\mathrm{N}$ \\
\hline 7 & 1.8 & $\mathrm{Y}$ & $\mathrm{N}$ & $\mathrm{Y}$ & $\mathrm{N}$ & $\mathrm{N}$ & $\mathrm{Y}$ & $\mathrm{N}$ & $\mathrm{N}$ & $\mathrm{N}$ \\
\hline 8 & 4 & $\mathrm{~N}$ & $\mathrm{~N}$ & $\mathrm{~N}$ & $\mathrm{~N}$ & $\mathrm{~N}$ & $\mathrm{Y}$ & $\mathrm{N}$ & $\mathrm{N}$ & $\mathrm{N}$ \\
\hline 9 & 1.3 & $\mathrm{~N}$ & $\mathrm{~N}$ & $\mathrm{~N}$ & $\mathrm{Y}$ & $\mathrm{Y}$ & $\mathrm{Y}$ & $\mathrm{Y}$ & $\mathrm{N}$ & $\mathrm{Y}$ \\
\hline 10 & 1.5 & $\mathrm{~N}$ & $\mathrm{~N}$ & $\mathrm{~N}$ & $\mathrm{Y}$ & $\mathrm{N}$ & $\mathrm{N}$ & $\mathrm{N}$ & $\mathrm{N}$ & $\mathrm{N}$ \\
\hline 11 & 7.5 & $\mathrm{~N}$ & $\mathrm{~N}$ & $\mathrm{~N}$ & $\mathrm{Y}$ & $\mathrm{N}$ & $\mathrm{N}$ & $\mathrm{Y}$ & $\mathrm{N}$ & $\mathrm{N}$ \\
\hline 12 & 1 & $\mathrm{Y}$ & $\mathrm{N}$ & $\mathrm{N}$ & $\mathrm{N}$ & $\mathrm{N}$ & $\mathrm{N}$ & $\mathrm{N}$ & $\mathrm{N}$ & $\mathrm{N}$ \\
\hline 13 & 2.5 & $\mathrm{~N}$ & $\mathrm{~N}$ & $\mathrm{~N}$ & $\mathrm{~N}$ & $\mathrm{Y}$ & $\mathrm{N}$ & $\mathrm{Y}$ & $\mathrm{N}$ & $\mathrm{N}$ \\
\hline 14 & 6 & $\mathrm{Y}$ & $\mathrm{N}$ & $\mathrm{N}$ & $\mathrm{Y}$ & $\mathrm{N}$ & $\mathrm{N}$ & $\mathrm{N}$ & $\mathrm{N}$ & $\mathrm{N}$ \\
\hline 15 & 8 & $\mathrm{Y}$ & $\mathrm{Y}$ & $\mathrm{N}$ & $\mathrm{N}$ & $\mathrm{N}$ & $\mathrm{N}$ & $\mathrm{N}$ & $\mathrm{N}$ & $\mathrm{N}$ \\
\hline Total present & & 7 & 2 & 1 & 5 & 2 & 4 & 5 & 3 & 2 \\
\hline
\end{tabular}

circumference about the 90 th centile was seen in eight $(53 \%)$. However, vital signs indicative of rapidly rising intracranial pressure such as bradycardia $(20 \%)$ and apnoea $(20 \%)$ were not as common. Although there have been reports of retinal haemorrhages in the absence of NAI, there is a strong association between the sign and NAI. Retinal haemorrhages were present in 12 out of $15(80 \%)$ of our population.

Evidence of head trauma due to impact was seen in eight out of $15(53 \%)$ children. Six children had bruising to the head, and six had skull fractures. All had grossly abnormal computed tomograms, 13 with subdural haematomas and five showing cerebral oedema. As might be expected, other physical evidence of NAI was not confined to the head and nine children had suspicious soft tissue injuries (including bruising of differing ages and bite marks) and six had fractures (rib fractures, long bone fractures, and metaphyseal injuries).

The outcome at discharge for our NAI patients was depressing. There was no difference between children with and without evidence of cranial impact. Two patients died. Of the survivors, nine out of $13(69 \%)$ showed major neurological handicaps and three showed moderate injury. Only one survivor was considered normal at discharge. Follow up varied between three months and three years and showed only one child with apparently normal outcome (at three months), seven (54\%) were described as severely handicapped (physical and mental, totally dependent), four (31\%) had moderate handicap (severe hemiparesis, blindness, developmental delay) with one mildly handicapped (hemiparesis and seizures) (table 3).

Our comparison group consisted of 10 patients admitted over the same period with known accidental trauma. All patients of a comparable age $(<2$ years) were included in the comparison. Table 4 shows details of the trauma, radiological findings, and outcome. Despite similar evidence of traumatic injury, the outcome at hospital discharge showed that six out of nine $(67 \%)$ patients were thought to be normal, one (11\%) was only mildly damaged, and one (11\%) had severe neurological damage; one patient died.

Long term social outcomes in the NAI patients, in terms of current care conditions and prosecutions, was surprising. There were only three prosecutions (all successful), one for manslaughter and two for wilful neglect. One prosecution is outstanding. Only six children remain under the protection of a care order. Five have been returned to both parents, four to the care of one parent, and three have been fostered. One child is being cared for by her paternal grandmother.

Table 2 Findings on physical examination at admission ( $Y=$ present; $N=$ not present $)$

\begin{tabular}{|c|c|c|c|c|c|c|c|c|c|c|}
\hline $\begin{array}{l}\text { Child } \\
\text { No }\end{array}$ & Bradycardia & Apnoea & Hypothermia & Irritability & Lethargy & Coma & $\begin{array}{l}\text { Full } \\
\text { fontanelle }\end{array}$ & $\begin{array}{l}\text { Head } \\
\text { circumference } \\
>90 \text { th centile }\end{array}$ & $\begin{array}{l}\text { Neck } \\
\text { stiffness }\end{array}$ & Seizures * \\
\hline 1 & $\mathrm{~N}$ & $\mathrm{~N}$ & $\mathrm{~N}$ & $\mathrm{~N}$ & $\mathrm{Y}$ & $\mathrm{N}$ & $\mathrm{Y}$ & $\mathrm{N}$ & $\mathrm{N}$ & $\mathrm{Y}$ \\
\hline 2 & $\mathrm{~N}$ & $\mathrm{~N}$ & $\mathrm{~N}$ & $\mathrm{Y}$ & $\mathrm{N}$ & $\mathrm{N}$ & $\mathrm{Y}$ & $\mathrm{Y}$ & $\mathrm{N}$ & $\mathrm{N}$ \\
\hline 3 & $\mathrm{Y}$ & $\mathrm{N}$ & $\mathrm{N}$ & $\mathrm{N}$ & $\mathrm{N}$ & $\mathrm{Y}$ & $\mathrm{N}$ & $\mathrm{N}$ & $\mathrm{N}$ & $\mathrm{N}$ \\
\hline 4 & $\mathrm{~N}$ & $\mathrm{~N}$ & $\mathrm{~N}$ & $\mathrm{Y}$ & $\mathrm{N}$ & $\mathrm{N}$ & $\mathrm{Y}$ & $\mathrm{Y}$ & $\mathrm{Y}$ & $\mathrm{Y}$ \\
\hline 5 & $\mathrm{~N}$ & $\mathrm{~N}$ & $\mathrm{~N}$ & $\mathrm{Y}$ & $\mathrm{N}$ & $\mathrm{N}$ & $\mathrm{N}$ & $\mathrm{Y}$ & $\mathrm{Y}$ & $\mathrm{Y}$ \\
\hline 6 & $\mathrm{~N}$ & $\mathrm{Y}$ & $\mathrm{Y}$ & $\mathrm{N}$ & $\mathrm{N}$ & $\mathrm{N}$ & $\mathrm{Y}$ & $\mathrm{Y}$ & $\mathrm{N}$ & $\mathrm{Y}$ \\
\hline 7 & $\mathrm{~N}$ & $\mathrm{Y}$ & $\mathrm{N}$ & $\mathrm{N}$ & $\mathrm{Y}$ & $\mathrm{N}$ & $\mathrm{Y}$ & $\mathrm{Y}$ & $\mathrm{N}$ & $\mathrm{Y}$ \\
\hline 8 & $\mathrm{Y}$ & $\mathrm{Y}$ & $\mathrm{Y}$ & $\mathrm{N}$ & $\mathrm{N}$ & $\mathrm{N}$ & $\mathrm{Y}$ & $\mathrm{N}$ & $\mathrm{N}$ & $\mathrm{Y}$ \\
\hline 9 & $\mathrm{~N}$ & $\mathrm{~N}$ & $\mathrm{~N}$ & $\mathrm{~N}$ & $\mathrm{~N}$ & $\mathrm{Y}$ & $\mathrm{Y}$ & $\mathrm{Y}$ & $\mathrm{N}$ & $\mathrm{Y}$ \\
\hline 10 & $\mathrm{~N}$ & $\mathrm{~N}$ & $\mathrm{~N}$ & $\mathrm{~N}$ & $\mathrm{~N}$ & $\mathrm{Y}$ & $\mathrm{Y}$ & $\mathrm{Y}$ & $\mathrm{N}$ & $\mathrm{N}$ \\
\hline 11 & $\mathrm{~N}$ & $\mathrm{Y}$ & $\mathrm{N}$ & $\mathrm{Y}$ & $\mathrm{N}$ & $\mathrm{N}$ & $\mathrm{Y}$ & $\mathrm{N}$ & $\mathrm{N}$ & $\mathrm{Y}$ \\
\hline 12 & $\mathrm{Y}$ & $\mathrm{Y}$ & $\mathrm{Y}$ & $\mathrm{Y}$ & $\mathrm{N}$ & $\mathrm{N}$ & $\mathrm{N}$ & $\mathrm{N}$ & $\mathrm{N}$ & $\mathrm{Y}$ \\
\hline 13 & $\mathrm{~N}$ & $\mathrm{~N}$ & $\mathrm{~N}$ & $\mathrm{Y}$ & $\mathrm{N}$ & $\mathrm{N}$ & $\mathrm{Y}$ & $\mathrm{N}$ & $\mathrm{Y}$ & $\mathrm{Y}$ \\
\hline 14 & $\mathrm{~N}$ & $\mathrm{~N}$ & $\mathrm{~N}$ & $\mathrm{~N}$ & $\mathrm{~N}$ & $\mathrm{~N}$ & $\mathrm{~N}$ & $\mathrm{~N}$ & $\mathrm{~N}$ & $\mathrm{Y}$ \\
\hline 15 & $\mathrm{~N}$ & $\mathrm{Y}$ & $\mathrm{N}$ & $\mathrm{N}$ & $\mathrm{N}$ & $\mathrm{Y}$ & $\mathrm{N}$ & $\mathrm{Y}$ & $\mathrm{N}$ & $\mathrm{Y}$ \\
\hline Total present & 3 & 6 & 3 & 6 & 2 & 4 & 10 & 8 & 3 & 12 \\
\hline
\end{tabular}

^At any point during admission. 
Table 3 Evidence of trauma in patients in NAI group and outcome ( $Y=$ present; $N=$ not present)

\begin{tabular}{|c|c|c|c|c|c|c|c|c|c|c|c|}
\hline $\begin{array}{l}\text { Child } \\
\text { No }\end{array}$ & $\begin{array}{l}\text { Bruising to } \\
\text { head }\end{array}$ & $\begin{array}{l}\text { Soft tissue } \\
\text { injury }\end{array}$ & $\begin{array}{l}\text { Skull } \\
\text { fracture }\end{array}$ & $\begin{array}{l}\text { Other } \\
\text { fractures }\end{array}$ & $\begin{array}{l}\text { Retinal } \\
\text { haemorrhage }\end{array}$ & $\begin{array}{l}\text { Subdural } \\
\text { haematomas }\end{array}$ & $\begin{array}{l}\text { Cerebal } \\
\text { oedema }\end{array}$ & $\begin{array}{l}\text { Subarachnoid } \\
\text { haematomas }\end{array}$ & $\begin{array}{l}\text { Outcome at } \\
\text { discharge }\end{array}$ & $\begin{array}{l}\text { Follow up } \\
\text { interval } \\
\text { (months) }\end{array}$ & $\begin{array}{l}\text { Outcome at } \\
\text { follow up }\end{array}$ \\
\hline 1 & $\mathrm{~N}$ & $\mathrm{Y}$ & $\mathrm{N}$ & $\mathrm{Y}$ & $\mathrm{N}$ & $\mathrm{Y}$ & $\mathrm{N}$ & $\mathrm{N}$ & Severe & 4 & Severe \\
\hline 2 & $\mathrm{Y}$ & $\mathrm{N}$ & $\mathrm{Y}$ & $\mathrm{Y}$ & Bilateral & $\mathrm{N}$ & $\mathrm{Y}$ & $\mathrm{N}$ & Severe & 36 & Severe \\
\hline 3 & $\mathrm{Y}$ & $\mathrm{Y}$ & $\mathrm{Y}$ & $\mathrm{Y}$ & Bilateral & $\mathrm{Y}$ & $\mathrm{N}$ & $\mathrm{N}$ & Severe & 20 & Severe \\
\hline 4 & $\mathrm{~N}$ & $\mathrm{~N}$ & $\mathrm{~N}$ & $\mathrm{~N}$ & $\mathrm{~N}$ & $\mathrm{Y}$ & $\mathrm{N}$ & $\mathrm{N}$ & Severe & 3 & Moderate \\
\hline 5 & $\mathrm{Y}$ & $\mathrm{Y}$ & $\mathrm{N}$ & $\mathrm{N}$ & Bilateral & $\mathrm{Y}$ & $\mathrm{N}$ & $\mathrm{N}$ & Moderate & 24 & Moderate \\
\hline 6 & $\mathrm{~N}$ & $\mathrm{Y}$ & $\mathrm{N}$ & $\mathrm{N}$ & Right & $\mathrm{Y}$ & $\mathrm{N}$ & $\mathrm{N}$ & Severe & 24 & Moderate \\
\hline 7 & $\mathrm{~N}$ & $\mathrm{~N}$ & $\mathrm{Y}$ & $\mathrm{Y}$ & Bilateral & $\mathrm{Y}$ & $\mathrm{Y}$ & $\mathrm{Y}$ & Severe & 24 & Severe \\
\hline 8 & $\mathrm{~N}$ & $\mathrm{Y}$ & $\mathrm{N}$ & $\mathrm{N}$ & Bilateral & $\mathrm{N}$ & $\mathrm{Y}$ & $\mathrm{Y}$ & Severe & 10 & Severe \\
\hline 9 & $\mathrm{~N}$ & $\mathrm{Y}$ & $\mathrm{N}$ & $\mathrm{Y}$ & Bilateral & $\mathrm{Y}$ & $\mathrm{Y}$ & $\mathrm{Y}$ & Died & - & - \\
\hline 10 & $\mathrm{Y}$ & $\mathrm{Y}$ & $\mathrm{Y}$ & $\mathrm{N}$ & Bilateral & $\mathrm{Y}$ & $\mathrm{Y}$ & $\mathrm{Y}$ & Died & - & - \\
\hline 11 & $\mathrm{Y}$ & $\mathrm{Y}$ & $\mathrm{N}$ & $\mathrm{N}$ & $\mathrm{N}$ & $\mathrm{Y}$ & $\mathrm{N}$ & $\mathrm{N}$ & Normal & 3 & Normal \\
\hline 12 & $\mathrm{~N}$ & $\mathrm{~N}$ & $\mathrm{~N}$ & $\mathrm{~N}$ & Bilateral & $\mathrm{Y}$ & $\mathrm{N}$ & $\mathrm{Y}$ & Moderate & 12 & Severe \\
\hline 13 & $\mathrm{~N}$ & $\mathrm{~N}$ & $\mathrm{Y}$ & $\mathrm{Y}$ & Bilateral & $\mathrm{Y}$ & $\mathrm{N}$ & $\mathrm{N}$ & Severe & 6 & Mild \\
\hline 14 & $\mathrm{Y}$ & $\mathrm{Y}$ & $\mathrm{Y}$ & $\mathrm{N}$ & Bilateral & $\mathrm{Y}$ & $\mathrm{N}$ & $\mathrm{Y}$ & Moderate & 15 & Moderate \\
\hline 15 & $\mathrm{~N}$ & $\mathrm{~N}$ & $\mathrm{~N}$ & $\mathrm{~N}$ & Bilateral & $\mathrm{Y}$ & $\mathrm{N}$ & $\mathrm{N}$ & Severe & 12 & Severe \\
\hline Total present & 6 & 9 & 6 & 6 & 12 & 13 & 5 & 6 & & & \\
\hline
\end{tabular}

Table 4 Mechanism of injury, radiological findings, and outcome at discharge of accidental impact trauma group

\begin{tabular}{|c|c|c|c|}
\hline $\begin{array}{l}\text { Child } \\
\text { No }\end{array}$ & Mechanism & Findings from scan & $\begin{array}{l}\text { Outcome at } \\
\text { discharge }\end{array}$ \\
\hline 1 & Fall & $\begin{array}{l}\text { Fractured skull, } \\
\text { contusion }\end{array}$ & Normal \\
\hline 2 & Fall & $\begin{array}{l}\text { Fractured skull, IC } \\
\text { bleed }\end{array}$ & Died \\
\hline 3 & Fall & $\begin{array}{l}\text { Fractured skull, IC } \\
\text { bleed }\end{array}$ & Normal \\
\hline 4 & Fall & Fractured skull & Normal \\
\hline 5 & Fall & IC bleed & Mild handicap \\
\hline 6 & RTA & $\begin{array}{l}\text { Fractured skull, } \\
\text { contusion }\end{array}$ & $\begin{array}{l}\text { Severe } \\
\text { handicap }\end{array}$ \\
\hline 7 & RTA & $\begin{array}{l}\text { Contusion, IC } \\
\text { bleed }\end{array}$ & Normal \\
\hline 8 & RTA & Normal & Normal \\
\hline 9 & $\begin{array}{l}\text { Struck by } \\
\text { hammer }\end{array}$ & Fractured skull & Normal \\
\hline 10 & $\begin{array}{l}\text { Kicked by } \\
\text { horse }\end{array}$ & $\begin{array}{l}\text { Fractured skull, IC } \\
\text { bleed }\end{array}$ & Normal \\
\hline
\end{tabular}

$\mathrm{RTA}=$ road traffic accident, IC bleed=intracranial bleed .

\section{Discussion}

All the children studied were diagnosed with shaken baby syndrome, a clinical entity first described by Caffey in $1972 .^{9}$ This syndrome is characterised by retinal haemorrhages, subdural and/or subarachnoid haemorrhages, and minimal or absent signs of external trauma. ${ }^{10} 11$ It remains, however, a somewhat hypothetical concept as a reliable history is almost never obtained, and the role of impact and acceleration/deceleration is still unclear. These injuries have been recognised as the most serious in the spectrum of child abuse with high morbidity and mortality, ${ }^{1241012}$ and are thus the most likely consequence of NAI to be seen in PICUs. Our study only includes 15 cases, so the information contained in it is anecdotal rather than statistical. Also, long term follow up times from discharge are unequal (three months to three years), but there are still important issues raised by these data.

The physical outcome of these children at discharge from PICUs was depressing, with two deaths and a very high incidence of handicap consistent with other reviews. ${ }^{1-3}$ This high level of short term morbidity is certainly not predicted by the mildness of the presenting symptoms. Furthermore, this is in marked contrast to the presentation and morbidity at discharge of the children admitted for severe accidental head injury. In all children, com- puted tomography showed extensive intracranial damage (cerebral oedema, subdural, or subarachnoid haemorrhages). Magnetic resonance imaging was performed in some, but not all, of these children and we have therefore not reported these findings. It is well known, however, that this imaging may yield greater information as to the aetiology and timing of different brain injuries.

The long term outcome of the NAI group in the study is particularly bad, and only three children showed signs of improvement over time. It must be noted, however, that the follow up assessment of neurological disability was not corroborated by our personal clinical examination, but assessed from outpatient reports and from key careworkers involved. We know from the series of Bonnier et al of 13 children that the follow up interval is important and that a symptom free period may precede significant neurological disability. ${ }^{5}$ A longer follow up study may be needed to bring to light the full extent of injury. There are few other data on the long term outcome of shaking injuries. In Bonnier's study only one patient appeared to be normal at a six year follow up. The long term influence of these injuries is thus wholly out of proportion to the initial presentation. This is the reverse of those accidentally injured, where most recovered completely.

We believe that the differences between the two groups is explained in the main part by the different mechanisms of injury. Duhaime et al, who studied head injury in very small children, concluded that rotational forces (that is, shaking) predominated in the most severe head injuries. ${ }^{6}$ What is unclear, however, is the role of impact in the shaking injury and whether shaking alone can create sufficient acceleration/ deceleration forces to cause severe neurological injury and death. ${ }^{1}$ Many authors postulate that the repetitive flexion and extension of an infant head and neck can result in shearing force injuries of vascular and neuronal structures to cause intracranial and retinal haemorrhage, oedema, contusional tears, and disturbance of brain growth. ${ }^{17}$ Duhaime et al, have recently disputed this and suggest that direct cranial impact is an essential component of the pathophysiology of the injury syndrome. ${ }^{8}$ Their 
model does not, however, simulate the rotational and shearing forces within the brain on vessels and neurones where the damage occurs, ${ }^{13}$ nor does it take into account the possibility that the propensity for damage may be increased by the repetitive nature of the injury rather than the size of the force alone. Thus the force, duration, and frequency of shakes and the age of the child may all be important in assessing the extent of the damage. Our two groups (NAI and trauma) had comparable evidence of trauma and thus acceleration/deceleration injury, but profoundly different outcomes. This suggests a different mechanism for the damage and we would postulate that shearing forces from shaking are the most likely explanation. This is further supported by the fact that seven of the 15 patients with NAI had no external head trauma.

SOCIAL AND LEGAL OUTCOMES

Social outcomes at the point of follow up surprised us considering the nature of the inflicted injuries. Nine of the 15 children returned to their previous homes with no successful prosecutions being made. Each case needs to be examined critically before commenting on the judicial process, but our observation is consistent with the well known lack of successful prosecutions for NAI. There were three convictions: a father for manslaughter on the forensic evidence of a bite mark and two mothers found guilty of neglect.

We conclude that doctors should be aware that the symptoms of severe NAI may be subtle and diverse. Meticulous documentation, together with a unified understanding of the mechanisms of injury, will strengthen our understanding of this condition and give us better confidence when commenting on the causes of specific injuries in children. Our findings add support to the evidence that shaking an infant may be dangerous. We recommend a continuing campaign to increase public awareness of the dangers of shaking babies. ${ }^{14}$

1 Hadley MN, Sonntag VKH, Rekate HL, Murphy A. The infant whiplash-shake injury syndrome: a clinical and pathological study. Neurosurgery 1989;24:536-40

2 Ludwig S, Warman M. Shaken baby syndrome: a review of 20 cases. Ann Emerg Med 1984;13:104-7.

3 Frank Y, Zimmerman R, Leeds NMD. Neurological manifestations in abused children who have been shaken. Dev Med Child Neurol 1985;27:312-6.

4 Sarsfield JK. The neurological sequelae of non-accidental injury. Dev Med Child Neurol 1974;16:826-7.

5 Bonnier C, Nassogne M, Evrard P. Outcome and prognosis of whiplash shaken infant syndrome: late consequences after a symptom-free interval. Dev Med Child Neurol 1995; 37:943-56.

6 Duhaime AC, Alario AJ, Lewander WJ, et al. Head injury in very young children: mechanisms, injury types, and opthalvery young children: mechanisms, injury types, and opthal-
mologic findings in 100 hospitalised patients younger than 2 years of age. Pediatrics 1992;90:179-85.

7 Alexander R, Sato Y, Smith W, Bennett T. Incidence of impact trauma with cranial injuries ascribed to shaking. $\mathrm{Am}$ f Dis Child 1990;144:724-6.

8 Duhaime AC, Gennarelli TA, Thibault LE, Bruce DA, Margulies SS, Wiser R. The shaken baby syndrome. $\mathcal{f} \mathrm{Neu}$ rosurg 1987;66:409-15.

9 Caffey J. Brain damage from whiplash-shaking of infants. Am $\mathcal{F}$ Dis Child 1972;124:161-9.

10 Wilkinson WS, Han DP, Rappley MD, Owings CL. Retinal hemorrhage predicts neurologic injury in the shaken baby syndrome. Arch Ophthamol 1989;107:1472-4.

11 Zimmerman J, Bilaniuk LT, Bruce D, Schut L, Uzzell B, Goldberg HI. Interhemispheric acute subdural hematoma: shaking. Neuroradiology 1978;16:39-40.

12 Sinal AH, Ball MR. Head trauma due to child abuse: serial computerised tomography in diagnosis and management.
comal AH, Ball MR. Head trauma due to child abuse: serial South Med F 1996;80:1505-12.

13 Brown JK, Minns RA. Non-accidental head injury, with particular reference to whiplash shaking injury and medico-legal aspects. Dev Med Child Neurol 1993;35:84969.

14 Carty H, Ratcliffe J. The shaken infant syndrome. BMf 1995;310:344-5. 